\title{
Berpikir Kritis dalam Skripsi Mahasiswa
}

\author{
Nurcaya \\ Universitas Puangrimaggalatung \\ nurcaya.aydin17@gmail.com
}

\begin{abstract}
Abstrak
Penelitian ini bertujuan mendeskripsikan berpikir kritis dalam skripsi mahasiswa berdasarkan aspek interpretasi, analisis, dan inferensi.Berpikir kritis dipilih sebagai topik penelitian ini karena dianggap penting dalam penulisan skripsi agar mahasiswa tidak hanya sekadar memahami, tetapi juga ikut menyumbangkan gagasannya untuk memberikan solusi dalam mengatasi sebuah permasalahan.Teks editorial dipilih karena saat menulis teks editorial dibutuhkan daya pikir yang kritis dan kreatif untuk menyampaikan pendapat atau argumen penulis tentang permasalahan yang aktual kepada pembaca. Oleh karena itu, penelitian ini menggunakan pendekatan kualitatif dengan desain penelitian studi dokumen. Data penelitian ini berupa paparan verbal tulis yang megandung aspek interpretasi, analisis, dan inferensi.Sumber data penelitian ini yaitu skripsi mahasiswa STKIP Prima Sengkang. Prosedur pengumpulan data penelitian ini menggunakan studi dokumen. Pengumpulan data dilakukan dengan mengidentifikasi data yang layak diteliti, merekam data ke dalam tabel penyajian data, dan memberikan kode pada masing-masing data. Instrumen utama dalam penelitian ini adalah peneliti sendiri dengan dibantu intrumen tambahan berupa panduan analisis data. Kegiatan analisis data dilakukan dengan reduksi data, penyajian data, dan penarikan kesimpulan. Hasil penelitian ini sebagai berikut. Pada aspek interpretasi ditemukan beberapa judul yang memiliki kemiripan, hanya yang membedakan waktu dan tempat. Pada aspek analisis yang dilakukan dengan menguji gagasan. Dalam hal ini ditemukan hasil bahwa mahasiswa mampu menemukan dan mengolah data secara kritis. Pada aspek inferensi, mahasiswa dapat membangun prinsip sendiri dan menginferensi konsep yang ada.
\end{abstract}

Kata Kunci: berpikir kritis, skripsi

\section{Pendahuluan}

Kualitas pendidikan di Indonesia perlu terus ditingkatkan dalam rangka menghadapi persaingan di era globalisasi. Persiapan sumber daya manusia yang berkualitas di Perguruan Tinggi merupakan faktor kunci menuju kemajuan masyarakat atau bangsa. Peningkatan mutu pendidikan tersebut diarahkan pada upaya untuk menciptakan output yang berkualitas dan siap terjun ke pasar kerja. Kecakapan yang perlu dimiliki mahasiswa dalam pembelajaran abad 21 adalah 4C (Critical thinkingproblem solving, creative-innovative, communicative dan collaborative). Berpikir kritis adalah kemampuan yang dibutuhkan dalam segala aspek kehidupan.Berpikir kritis faktor esensial untuk bekal disemua aktifitas kehidupan (Subekti, 2018). Pakar pendidikan sebenarnya telah lama menyadari pentingnya keterampilan berpikir kritis sebagai salah satu hasil dari proses pembelajaran. Saat ini, partnership for $21^{\text {st }}$ Century skils telah mengidentifikasi bahwa keterampilan berpikir kritis menjadi salah satu dari beberapa kemampuan yang dibutuhkan untuk menyiapkan mahasiswa pada jenjang pendidikan dan dunia kerja (Bell R \& Loon, M, 2014).

Berbagai dunia kerja membutuhkan keterampilan berpikir kritis. Manfaat kebiasaan berpikir kritis adalah untuk mendapatkan solusi dari sebuah permasalahan kehidupan. Keterampilan berpikir kritis dapat digunakan mahasiswa dalam berargumen dengan kebenaran ilmiah, memiliki mental spiritual, dan terampil 
mengambil keputusan. Bahkan menurut Liliasari (2001) keterampilan berpikir kritis merupakan salah satu modal dasar atau modal intelektual yang sangat penting bagi setiap orang dan merupakan bagian yang fundamental dari kematangan manusia.

Berpikir kritis mengandung aktifitas mental dalam hal memecahkan masalah, menganalisis asumsi, memberikan rasional, mengevaluasi, melakukan penyelidikan, dan mengambil keputusan (Gunawan, 2003:177-178).Berpikir kritis sebagai sebuah keterampilan berorientasi hasil, pada akhirnya akan diuji seberapa jauh signifikansinya antara yang diprediksikan dengan kenyataan di masa depan. Penelitian terkait hal (berpikir kritis sebagai kemampuan prediktif) ini telah dilakukan oleh Butler, H. A., Pentoney, C, \& Bong, M. P. (2017:3) yang hasilnya, yakni a) berpikir kritis dan kecerdasan untuk meramalkan kejadian nyata, b) mereka yang lebih tinggi dalam berpikir kritis dan cerdas dilaporkan lebih sedikit peristiwa kehidupannya negatif, dan c) berpikir kritis adalah prediktor kuat dunia nyata dari kecerdasan.

Kecakapan berpikir kritis pada dasarnya harus dilatih sejak kecil dalam kehidupan sehari-hari (Molan, 2012). Pada proses pembelajaran, berpikir kritis bisa dikembangkan dalam pembelajaran berdasarkan aspek kerja ilmiah.Pembelajaran berpikir tersebut meliputi aktifitas multisegi yang menggunakan kapasitas otak atau pikiran untuk mengidentifikasi objek, merancang, mengorganisir sumber daya, dan menitor yang melibatkan aktifitas kognitif (Kuswana, 2014).Aktifitas kognitif terkait pada mempelajari dan mengembangkan ide-ide, penemuan dan penciptaan, untuk memecahkan berbagai permasalahan kehidupan.

Kegiatan berpikir kritis dapat terjadi ketika seseorang mengalami suatu situasi yang mendorongnya untuk berpikir kritis, misalnya suatu masalah yang sedang dialaminya.Sesuai dengan ungkapan Zeirulista, dkk (2016), bahwa seseorang membutuhkan keterampilan berpikir kritis untuk dapat memecahkan masalah dengan baik. Selain itu, In'am (2014) mengatakan bahwa ketika siswa memecahkan suatu masalah, pemikiran kritis sangat penting untuk dilakukan, sehingga setelah siswa memahami masalahnya, mereka dapat membuat rencana sebagai upaya untuk menemukan solusi dan dalam perencanaan tersebut, pemilihan ide yang tepat sangat mempengaruhi kebenaran solusi, ide cemerlang itu dapat diperoleh jika pemikiran kritis selalu digunakan ketika melihat suatu permasalahan. Kemudian menurut Karatas (2013) pemecahan masalah merupakan suatu keterampilan hidup yang penting untuk melibatkan berbagai proses kognitif termasuk menganalisis, menafsirkan, menalar, memprediksi, mengevaluasi dan merefleksi.

Artikel yang ditulis oleh Sultan (2013) menjelaskan bahwa mahasiswa di Universitas Inggris masih mengalami kesulitan dalam menulis akademis. Artikel ini melaporkan sebuah penelitian yang dirancang untuk menyoroti beberapa alasan kurangnya keterampilan menulis, dengan maksud untuk mengidentifikasi langkahlangkah perbaikan yang dapat diambil untuk mengatasi masalah. Salah satu langkah yang diambil untuk mengatasi masalah yang ada yaitu siswa didorong untuk fokus pada pertanyaan dan untuk mengembangkan argumen, menunjukkan pemikiran kritis dan, akhirnya, bagaimana menggunakan ulasan dan umpan balik yang baik. Para siswa mengidentifikasi kata-kata kunci dan apa artinya bagi mereka dalam proses penelitian Melalui proses memiliki siswa mengidentifikasi dengan tepat apa pertanyaan penelitian itu, menggunakan umpan ke depan, dan melalui proses menjelaskan reaksi pertama mereka dan apa yang mereka ketahui tentang subjek, mereka mulai memahami persyaratan proses penulisan. Bastug, dkk (2017) dalam artikelnya menjelaskan bahwa 
penyebab ketidakmampuan untuk memulai atau melanjutkan menulis adalah kurangnya kegiatan menulis yang memungkinkan siswa untuk menginterpretasi dan mengekspresikan diri dengan bebas, melakukan tes konstan dan tidak cukupnya peluang untuk menulis dianggap sebagai alasan utama untuk blok penulis.Karakteristik yang diinterpretasikan dibawah konsep kekurangan afektif menulis, kurangnya informasi, kurangnya pengalaman menulis, dan perasaan dikendalikan. Kekurangan afektif siswa menyebabkan mereka menderita blok penulis. Kurangnya kepercayaan diri; fakta bahwa mereka tidak yakin tentang tulisan mereka, mereka tidak menganggap diri mereka sebagai baik; ketakutan yang mereka miliki; dan perasaan gagal dan putus asa dianggap di antara penyebab blok penulis berdasarkan ketidakefektifan afektif. Menurut temuan penelitian ini, pengalaman afektif negatif siswa menyebabkan mereka menderita blok penulis.

Penulisan skripsi memberikan pengalaman belajar kepada mahasiswa dalam menyelesaikan masalah secara ilmiah, dengan cara melakukan penelitian sendiri, menganalisis serta menarik kesimpulan, dan menulisnya menjadi bentuk karya ilmiah. Keharusan menulis skripsi dimaksudkan agar mahasiswa mampu menerapkan ilmu dan kemampuan sesuai dengan disiplin ilmu yang dimiliki kedalam kenyataan yang dihadapi dan yang tidak kalah penting, skripsi merupakan tolak ukur sejauhmana tingkat pemahaman mahasiswa terhadap ilmu yang dimilikinya. Skripsi merupakan bukti kemampuan akademik dalam melakukan penelitian terhadap kasus-kasus atau fenomena yang muncul dan kemudian diteliti dengan menggunakan teori-teori yang relevan dan kemudian akan dianalisis untuk mendapat hasil dari penelitian tersebut. Sehingga sangat penting bagi mahasiswa untuk segera menyelesaikan skripsinya sebagai bagian dari persyaratan pendidikan akademis di perguruan tinggi.

Hasil observasi awal ditemukan bahwa ketika mahasiswa menyelesaikan skripsinya terdapat beberapa faktor yang mempengaruhi, salah satunya adalah gaya kognitif. Seperti hasil wawancara yang dilakukan oleh penulis kepada salah seorang mahasiswa, bahwa mahasiswa tersebut agak lambat berjalan penyelesaian penulisan skripsinya karena mahasiswa tersebut kurang paham dengan apa yang dimaksud dosen pembimbingnya. Permasalahan lain yang muncul pada saat penyelesaian skripsi yakni kesulitan mencari literatur, dana yang terbatas, tidak terbiasamenulis dalam arti menulis karya ilmiah, kurang terbiasa dengan sistem kerjaterjadwal dengan pengaturan waktu sedemikian ketat dan masalah dengan dosenpembimbing skripsi.Tujuan dari penelitian ini yaitu mendeskripsikan proses berpikir kritis mahasiswa STKIP Prima Sengkang dalam menyelesaikan skripsi yang merupakan syarat untuk mendapatkan gelar sarjana.Fokus penelitian ini adalah memaparkan kemampuan berpikir kritis dalam makalah argumentasi mahasiswa yang meliputi aspekinterpretasi, analisisis,inferensi.

\section{Metode Penelitian}

Penelitian ini menggunakan jenis penelitian kualitatif.Penelitian kualitatif merupakan jenis penelitian yang menekankan kepada pendalaman dan interpretasi data dalam bentuk deskripsi.Sumber data dalam penelitian ini adalah tulisan skripsi mahasiswa.Data dalam penelitian ini berupa data verbal tulis dalam skripsi. Secara khusus, hal yang diteliti dalam data verbal tersebut adalah aspek interpretasi, analisis, dan inferensi berpikir mahasiswa dalam menulis skripsi. Data dalam penelitian ini 
yaitu catatan yang sudah direduksi terkait dengan perkembangan proses berpikir kritis dalam membahasakan gagasan. Teknik analisis data terdiri tiga alur kegiatan yang terjadi secara bersamaan yaitu: reduksi data, penyajian data, penarikan kesimpulan/verifikasi (Miles dan Hubberman, 1992:16). Ketiga tahapan tersebut dilakukan secara bersama-sama setelah data terkumpul dan siap untuk disajikan. Analisis data yang akan dilakukan pada penelitian ini dilakukan mengikuti pedoman instrumen data berdasarkan fokus penelitian.

\section{Instrumen Pengumpulan Data}

Instrumen adalah alat bantu yang digunakan oleh peneliti saat menerapkan suatu metode dalam melakukan penelitian. Dalam penelitian ini, instrumen yang digunakan dalam pengumpulan data berupa panduan analisis data.Panduan analisis data berisi aspek, subaspek, temuan, data, dan kode untuk interpretasi, analisis, inferensi, elaborasi, dan redefinisi.Tabel panduan analisis data dapat dilihat sebagai berikut.

\begin{tabular}{|c|c|c|c|}
\hline Fokus & Aspek & Sub Aspek & Temuan \\
\hline \multirow[t]{5}{*}{ Berpikir Kritis } & Interpretasi & $\begin{array}{l}\text { Mengkategorisasikan } \\
\text { Ide }\end{array}$ & a. Topik permaslahan \\
\hline & Analisis & Menganalisis argumen & $\begin{array}{l}\text { a. argumen yang } \\
\text { mendukung } \\
\text { b. argumen yang } \\
\text { menyanggah }\end{array}$ \\
\hline & \multirow{3}{*}{ Inferensi } & $\begin{array}{l}\text { Menyangsikan } \\
\text { Argumen }\end{array}$ & $\begin{array}{ll}\text { bukti } & \text { yang } \\
\text { mendukung } & \\
\text { informasi } & \end{array}$ \\
\hline & & \multirow[t]{2}{*}{ Menarik Simpulan } & $\begin{array}{l}\text { a. Merumuskan } \\
\text { alternatif } \\
\text { pemecahan masalah }\end{array}$ \\
\hline & & & $\begin{array}{l}\text { b. memberikan } \\
\text { harapan }\end{array}$ \\
\hline
\end{tabular}

\section{Prosedur Pengumpulan Data}

Pengumpulan data dalam penelitian ini menggunakan studi dokumen.Peneliti memperoleh informasi dari dokumen yang berhubungan dengan responden. Pemerolehan data dengan teknik studi dokumen dilakukan peneliti dengan cara mengumpulkan skripsi mahasiswa tahun 2017.

\section{Hasil Penelitian dan Pembahasan}

Berpikir kritis mahasiswa dalam skripsi dapat dilihat dengan tiga aspek, yaitu: (1) interpretasi, (2) analisis, dan (3) inferensi. Ketiga aspek tersebut dibahas sebagai berikut.

\section{Aspek Interpretasi dalam Skripsi Mahasiswa}

Dalam skripsi mahasiswa aspek interpretasi berpikir, yaitu mengkategorikan tema tulisan. Kesulitan pertama mahasiswa dalam menyusun skripsi adalah saat pengajuan judul dan secara pintas yang dilakukan mahasiswa yaitu mengadopsi dari hasil skripsi orang lain tanpa memahami latar belakang masalah penelitian. sehingga kendala nampak saat pada proses penentuan analisa datanya. Dari data yang 
dikumpulkan, ada delapan mahasiswa memiliki tema atau judul yang dipilih memiliki kesamaan, hanya yang membedakan adalah wilayah atau tempat dan waktu penelitian. Hal menimbulkan ketidaksesuaian dengan fakta yang terjadi di lapangan. Sedangkan ada sepuluh mahasiswa memilih judul bertema sastra dan empat mahasiwa memilih judul tentang pengelolaan manajemen di sekolah. Dari temuan tersebut dapat memberikan gambaran bahwa kemampuan mahasiswa dalam menggali informasi maupun membaca hasil-hasil penelitian sebagai dasar dalam menyusun suatu penelitian masih dikategorikan kurang. Hal ini dipertegas Hakim (2021) dalam suatu penelitian bahwa kegiatan membaca, khususnya membaca artikel maupun referensi teori dapat menambah wawasan mahasiswa dan memeroleh informasi secara lebih mendalam.

\section{Aspek Analisis dalam Skripsi Mahasiswa}

Analisis berpikir dalam skripsima hasiswa dapat dilakukan dengan menguji gagasan. Salah satu ciri pemikir kritis adalah dapat membuat perbandingan. Membandingkan adalah memadukan dua hal untuk dicari perbedaan maupun persamaannya. Berdasarkan data dan hasil temuan penelitian, terdapat enam mahasiswa yang menuliskan perbandingan hasil penelitian. Dalam skripsi mahasiswa ditemukan perbandingan antara skripsi yang dijadikan rujukan. Apabila dua hal diperbandingkan akan diketahui perbedaan atau persamaan (Rani dkk, 2013:148). Dari skripsi mahasiswa, dapat menemukan perbedaan metode yang digunakan dalam penelitian serta hasil yang ditemukan akan berbeda pula. Dengan membuat perbandingan, berarti mahasiswa sudah mampu mengolah informasi secara kritis.

\section{Aspek Inferensi dalam Skripsi Mahasiswa}

Inferensi berpikir dalam skripsimahasiswa dapat dilakukan menarik simpulan. Pada tahap penarikan kesimpulan, mahasiswa melakukan review data yang ditemukan pada saat penelitian.Inferensi yang dilakukan mahasiswa berdasarkan fakta hasil serangkaian observasi.Hal ini menunjukkan bahwa mahasiswa tidak terburu-buru dalam mengambil kesimpulan.

\section{Simpulan}

Kondisi yang menunjukkan lemahnya penguasaan keilmuan mahasiswa STKIP Prima Sengkang, sedikit banyak juga dipengaruhi oleh lemahnya kemampuan serta kepekaan mereka untuk meneliti.Secara logika, sebenarnya naluri peneliti yang dimiliki oleh mahasiswa yang lemah berakibat pada ketidakmampuan mereka mencari peluang untuk lebih baik dalam menghadapi kehidupannya. Dalam lingkup mikro, tidak adanya orientasi akan ke mana dan apa yang akan dilakukan setelah menyelesaikan kuliah menyebabkan mahasiswa tidak berbuat apa-apa selain menjalani kehidupan apa adanya tanpa berupaya memperbaiki kondisi yang sedang mereka hadapi. Berbicara tentang penelitian di perguruan tinggi, arahnya adalah sesuai dengan Peraturan pemerintah No. 60 tahun 1999 bahwa penelitian akademis dilakukan agar mampu menemukan kebenaran dan atau menyelesaikan masalah dalam ilmu pengetahuan, teknologi dan atau kesenian. Untuk menciptakan paradigma dan teori-teori yang lebih relevan dengan masyarakat masih jauh dan butuh waktu.Karena itu kita harus bersikap kritis dalam memakai teori-teori yang datang dari luar. Untuk mencapai kelulusan menjadi sarjana boleh jadi dengan berbagai upayayang melanggar sekalipun termasuk melakukan plagiat atau duplikasi karya orang lain. Longgarnya proses pembimbingan penelitian oleh dosen juga terkait erat dan dapat mendorong terjadinya hal demikian. 
Karena itu duplikasi dan pengulangan-pengulangan penulisan skripsi akan terus menjadi fenomena yang tampak nyata dan terkesan biasa, bila kondisinya tidak segera diperbaiki.

\section{Daftar Pustaka}

Bastuq, dkk. 2017. A phenomenological research study on writer's block: causes, processes, and results. Emerald Publishing Limited, 59(6), 605-618.

Bell, R \& Loon, M (2014) -- The impact of critical thinking disposition on learning.docx

Butler, H. A., Pentoney, C, \& Bong, M. P. (2017) -- Kemampuan Berpikir Kritis adalah predictor lebih baik Keputusan hidup dari Intelligence.Thinking keterampilan dan Kreativitas .docx

Gunawan.Adi W. 2003. Genius Learning Strategy. Jakarta : Gramedia Pustaka Umum.

Hakim, M. N. (2021). Studi Tingkat Literasi Membaca Mahasiswa Selama Pembelajaran Daring. Bahtera Indonesia; Jurnal Penelitian Bahasa dan Sastra Indonesia, 6(1), 77-87.

In'am, A. 2014. The Implementation of the Polya Method in Solving Euclidean Geometry Problems. International Education Studies, 7(7), 149-158

Liliasari. (2001). Model Pembelajaran untuk Meningkatkan Keterampilan Berpikir Tingkat Tinggi Calon Guru sebagai Kecenderungan Baru pada Era Globalisasi. Jurnal Pengajaran MIPA 2 (1), 55.

Karatas, 2013.The Effect of Learning Environments Based on Problem Solving on Students Achievements of Problem Solving. International Electronic Journal of Elementary Education, 5(3), 249-268.

Kuswana, W.S. 2014.Taksonomi Kognitif. PT. Remaja Rosdakarya: Bandung.

Miles, M. B. \& Huberman, M. (1992).Analisis Data Kualitatif. Jakarta: Penerbit Universitas Indonesia

Molan, B. 2012.Logika (Ilmu dan Seni Berpikir Kritis). PT. Indeks: Jakarta.

Subekti, S. 2018. Mencetak Generasi Cerdas melalui Berpikir Kritis. CV. Cipta Media Edukasi: Surabaya.

Sultan, N. 2013.Can academia help improve the writing skills of tomorrow's professionals. Industry \& Higher Education,27(2), 139-147.

Rani, Abdul, dkk. 2010. Analisis Wacana; Sebuah Kajian Bahasa dalam Pemakaian. Malang: Bayu Media Publishing.

Zetriuslita, A. R., \& Nufus, H. 2016. Students Critical Thinking Ability: Description Based on Academic Level and Gender. Journal of Education and Practice, 7(12), 154-164. 